\title{
Metabolic assessment and enteral tube feeding usage in children with acute neurological diseases
}

\author{
Clinical Pediatrics Service, Hospital do Servidor Público Estadual “Francisco Morato de Oliveira”- São Paulo, Brazil
}

\begin{abstract}
Objective: To report on acquired experience of metabolic support for children with acute neurological diseases, emphasizing enteral tube feeding usage and metabolic assessment, and also to recommend policies aimed towards improving its implementation. Design: Retrospective analysis. Setting: Pediatric Intensive Care Unit of Hospital do Servidor Público Estadual de São Paulo. Subjects: 44 patients consecutively admitted to the Pediatric ICU over a period of 3 years who were given nutrition and metabolic support for at least 72 hours. Head trauma, CNS infections and craniotomy post-operative period following tumor exeresis were the main diagnoses. Measurements: Records of protein-energy intake, nutrient supply route, nitrogen balance and length of therapy. Results: From a total of 527 days of therapy, single parenteral nutrition was utilized for $34.3 \%$ and single enteral tube feeding for $79.1 \%$ of that period. $61.4 \%$ of the children were fed exclusively via enteral tube feeding, $9.1 \%$ via parenteral and $39.5 \%$ by both routes. The enteral tube feeding was introduced upon admission and transpyloric placement was successful in $90 \%$ of the cases. Feeding was started 48 hours after ICU admission. The caloric goal was achieved on the 7th day after admission, and thereafter parenteral nutrition was interrupted. The maximum energy supply was $104.2 \pm 23.15 \mathrm{kcal} / \mathrm{kg}$. The median length of therapy was 11 days (range 4-38). None of the patients on tube feeding developed GI tract bleeding, pneumonia or bronchoaspiration episodes and, of the 4 patients who were given exclusive TPN, 2 developed peptic ulcer. The initial urinary urea nitrogen was $7.11 \mathrm{~g} / \mathrm{m}^{2}$ and at discharge $6.44 \mathrm{~g} / \mathrm{m}^{2}$. The protein supply increased from $1.49 \mathrm{~g} / \mathrm{kg}$ to $3.65 \mathrm{~g} / \mathrm{kg}(\mathrm{p}<0.01)$. The nitrogen balance increased from 7.05 to $2.2 \mathrm{~g}(\mathrm{p}<0.01)$. Conclusions: Children with acute neurological diseases are hypercatabolic and have high urinary nitrogen losses. The initial negative nitrogen balance can be increased by more aggressive feeding regimes than the usual ones. Early tube feeding was well tolerated, which permits the conclusion that it is a safe and effective method for nutrition support. Recommendations of basic rules for metabolic support are made.
\end{abstract}

Uniterms: Enteral tube feeding. Nitrogen balance. Metabolic monitoring. Head injury.

\section{INTRODUCTION}

I $\mathrm{n}$ spite of the general knowledge that central nervous system (CNS) diseases can lead to impairment of nutritional status, up until the last decade only a few studies had demonstrated the need for implementation of early nutritional therapy in these cases. ${ }^{1}$

\author{
Address for correspondence: \\ Heitor Pons Leite \\ Rua Engenheiro Figueiredo, 11 \\ São Paulo/SP - Brasil - CEP 04012-150 \\ e-mail: heitorpl@zaz.com.br
}

Until then, the recommended method was the maintenance of fasting until full recovery of gastrointestinal function, which occurs at around one week after the onset of the injury. The nutritional support has to be instituted early, since these patients are considered at risk of malnutrition. In addition to the autocannibalism process resulting from the metabolic stress, ${ }^{2}$ there is the difficulty in delivering enteral nutrients to patients following head injury.

Impossibility of feeding by mouth and hypercatabolism are indications for nutritional support which, in its turn, can be a determining factor in the prognosis. ${ }^{3}$ Patients with CNS acute diseases are frequently in coma or have their swallowing reflexes impaired and need parenteral nutrition or enteral tube feeding. ${ }^{4,5}$ Even 
though the evidence favors enteral nutrition, due to its lower risk of complications and low cost, problems such as alteration of consciousness level and gastric motility abnormalities can delay the beginning of enteral tube feeding, leading to the more frequent use of parenteral nutrition in the first week following the neurological injury.

In view of the inherent difficulties in nutrient administration and with the aim of contributing to the study of problems related to nutritional and metabolic therapy in childen with CNS acute diseases, this study was developed to describe experience obtained with nutritional therapy in children with acute neurological diseases in a Pediatric Intensive Care Unit (PICU), with emphasis on the metabolic assessment and pattern of enteral nutrition, as well as recommending policies aimed at improving its implementation.

\section{METHODS}

Medical records of all patients with acute neurological diseases admitted to the PICU of Hospital do Servidor Público Estadual de São Paulo between June 1992 and January 1996 were analyzed. Of the total of 63 patients admitted during this period, the study included 44 who received nutritional therapy for at least 4 days. The remaining patients were excluded on the grounds of being discharged after less than 72 hours (11 patients) or having incomplete records. The age range was from 3 to 144 months (median: 68 months). Mechanical lung ventilation was used in 28 patients. The median Glasgow score of the patients with a diagnosis of head trauma and CNS infection at admission was 7 (range: 4 to 13). Table 1 shows the diagnosis at admission to the PICU.

The daily records of protein-energy delivery, initial nutritional assessment and metabolic monitoring were analyzed, from PICU admission until discharge. The nutritional assessment, performed within the first 72 hours after PICU admission, considered the weight/height measurements which were compared to NCHS standards. ${ }^{6}$ Nutritional status was obtained according to Waterlow's criteria. $^{7,8}$ The metabolic assessment was performed by determination of urinary urea nitrogen and nitrogen balance in those patients from whom it was possible to obtain 24 hour urine at admission and discharge from the PICU.

Urinary urea nitrogen determination was performed by the automated urease method. Nitrogen balance, obtained from the difference between nitrogen delivery and urinary losses, plus the estimated cutaneous and fecal
Table 1

Distribution of patients according to the diagnosis at admission.

\begin{tabular}{lc}
\hline Diagnosis & Frequency (\%) \\
\hline Head injury & $18(40.9 \%)$ \\
CNS infection & $12(27.3 \%)$ \\
CNS Tumor & $8(18.2 \%)$ \\
Miscellanea * & $6(13.6 \%)$ \\
\hline Total & 44
\end{tabular}

* Guillain Barré syndrome (4), spinal cord injury by gunfire (1), intracranial hypertension (1).

losses, was calculated according to Wilmore. ${ }^{9}$ The excretion of urinary urea nitrogen by the subjects with acute neurologic disease was compared to that obtained from other patients admitted with a diagnosis of sepsis who were followed up during the same period.

All patients received nutritional support, administered according to the unit's routine, following the standards of the American Society for Parenteral and Enteral Nutrition. ${ }^{10}$ Nutritional support is given to every child admitted into the unit, as of the moment they are hydrated and are in hemodynamic stability, initially given by the parenteral route. Parenteral nutrition is administered when enteral access cannot be obtained, when enteral nutrition support fails to meet nutritional requirements, and when feeding into the gastrointestinal tract is contraindicated. Solutions with dextrose concentration up to $12.5 \%$ are administered via peripheral vein, and those containing higher concentrations are infused via the central vein. Solutions are administered with lipid emulsions mixed in the same vial. When the digestive route cannot be used (due to presence of ileum, digestive hemorrhage or abdominal bloating) the nasoduodenal route is associated to the parenteral. Complete polymeric isoosmolar diets are employed, with a nitrogen to non-protein calorie ratio varying from 1:150 to $1: 100$, and a caloric content of $1.0 \mathrm{kcal} / \mathrm{ml}$. When there is intolerance, predigested commercial formulae with glucose polymers and protein hydrolyzates are used.

The placement of polyurethane tubing is as follows. The patient is placed in elevated decubitus at $30^{\circ}$, with prior administration of metoclopramide at $0.2 \mathrm{mg}$ per $\mathrm{kg}$ of body weight. After the tube is placed in the stomach, 20-30 ml of air are injected, with the patient maintained in lateral right decubitus to facilitate tube migration. Adequate post-pyloric position is confirmed by abdominal roentgenogram showing the tip of the tube placed between the second duodenal segment and the jejunum. The diet is administered by infusion pump, with the patient maintained 
in a right lateral position or raised at $30^{\circ}$ decubitus. The energy delivery is calculated according to Holliday \& Segar's rule. ${ }^{11}$ Delivery is initiated at $1 / 4$ of the total daily volume of estimated energy needs, increasing to half on the second day, $3 / 4$ on the third, and reaching the full provision by the fourth day. This scheme may be modified according to the patient's tolerance.

\section{Statistical analysis}

Considering the skewed distribution of the variable values, nonparametric methods were applied. The KruskalWallis variance analysis ${ }^{12}$ was used for comparing urinary urea nitrogen in the various disease groups. The Wilcoxon test ${ }^{12}$ was used for comparing values of nitrogen balance, urinary nitrogen losses and protein-caloric delivery at admission and discharge of the PICU. The Mann-Whitney test was used for comparing values of energy delivery according to the use of mechanical lung ventilation. Data analysis was performed on a CSS computer package (Statsoft, Inc., 1991). The level of significance was set at $5 \%$ for all analyses. Data were presented as median values and range and as mean $\pm \mathrm{SD}$.

\section{RESULTS}

Table 2 shows the nutritional status of the patients at time of admission to the PICU. Of the 44 patients studied, 27 received exclusively enteral tube feeding, 4 received exclusively parenteral nutrition and 13 received both forms of therapy. The enteral route was used for $79.9 \%$ and the parenteral route for $34.3 \%$ of a total period of 527 days of nutritional therapy.

The maximum energy delivery during hospital stay was $104.2 \pm 23.15 \mathrm{kcal} / \mathrm{kg}$, without significant variation between the different groups of neurological diseases. The planned energy amount was administered in its totality to 32 patients. No differences in energy supply was observed when patients who were under pulmonary mechanical

Table 2

Nutritional status at admission.

\begin{tabular}{lcc}
\hline Nutritional status & Frequency & $\%$ \\
\hline Eutrophy & 33 & $75 \%$ \\
Wasted & 3 & $6.8 \%$ \\
Wasted and stunted & 5 & $11.4 \%$ \\
Stunted & 3 & $6.8 \%$ \\
\hline
\end{tabular}

ventilation $(92.1 \pm 21.2 \mathrm{kcal} / \mathrm{kg})$ were compared to those who were not $(105.2 \pm 25.9 \mathrm{kcal} / \mathrm{kg} ; \mathrm{z}$ calculated $=1.5, \mathrm{z}$ critical $=1.96)$.

The median period for nutritional support was 11 days, with variation from 4 to 38 days. The enteral tube was inserted on the admission day, with successful migration to the duodenum in $90 \%$ of the cases. The median length of time between admission and the beginnning of postpyloric enteral feeding was 2 days, with one day being the necessary time for adequate tube placement. The estimated energy needs were satisfied by the seventh day after admission (Figure 2), when parenteral nutriton was suspended. No return to parenteral nutrition was needed in any of the cases and the transition was to the oral route in all cases.

The complications observed in the course of enteral tube feeding are shown in Table 3. None of the children submitted to enteral nutrition developed pneumonia, bronchoaspiration episodes, nor gastrointestinal tract bleeding. Of the four patients that received exclusively parenteral nutrition, two developed peptic ulcer, confirmed by endoscopy.

The comparison between excretion of urinary urea nitrogen by patients with different CNS diseases at admission and by patients with a diagnosis of sepsis is shown in Figure 3. Although the median value for septic patients $\left(10.12 \mathrm{~g} / \mathrm{m}^{2}\right)$ was higher than for patients with head trauma $\left(6.91 \mathrm{~g} / \mathrm{m}^{2}\right)$, with CNS infection $\left(8.5 \mathrm{~g} / \mathrm{m}^{2}\right)$ and those in the craniotomy post-operative period following tumor exeresis $\left(8.15 \mathrm{~g} / \mathrm{m}^{2}\right)$ there was no significant difference between the groups (calculated $\mathrm{H}=3.7$; critical $\mathrm{X}^{2}=7.81 ; \mathrm{p}=0.28$ ). There was a significant increase in nitrogen balance, which went from $-7.05 \mathrm{~g} / \mathrm{m}^{2}$ at admission to $2.2 \mathrm{~g} / \mathrm{m}^{2}$ at the time of discharge from the unit $(\mathrm{p}<0.01)$, as shown in Figure 4.

The urinary excretion of urea nitrogen at admission had a median value of $7.11 \mathrm{~g} / \mathrm{m}^{2}$ and of $6.44 \mathrm{~g} / \mathrm{m}^{2}$ at discharge, which was not a significant variation. On the other hand, protein delivery changed from $1.49 \mathrm{~g} / \mathrm{kg} /$ day at admission (range zero to $2.31 \mathrm{~g} / \mathrm{kg} /$ day) to $3.65 \mathrm{~g} / \mathrm{kg}$ / day (range 0.43 to $6.87 \mathrm{~g} / \mathrm{kg} / \mathrm{day}$ ), thus showing a significant increase $(\mathrm{p}<0.01)$.

Table 3

Complications of enteral tube feeding.

\begin{tabular}{lcc}
\hline Complication & Frequency & $\%$ \\
\hline Diarrhea & 6 & $15 \%$ \\
Tube obstruction & 4 & $10 \%$ \\
Abdominal bloating & 4 & $10 \%$ \\
Metabolic disturbance * & 2 & $5 \%$ \\
\hline${ }^{*}$ Hypernatremia & &
\end{tabular}




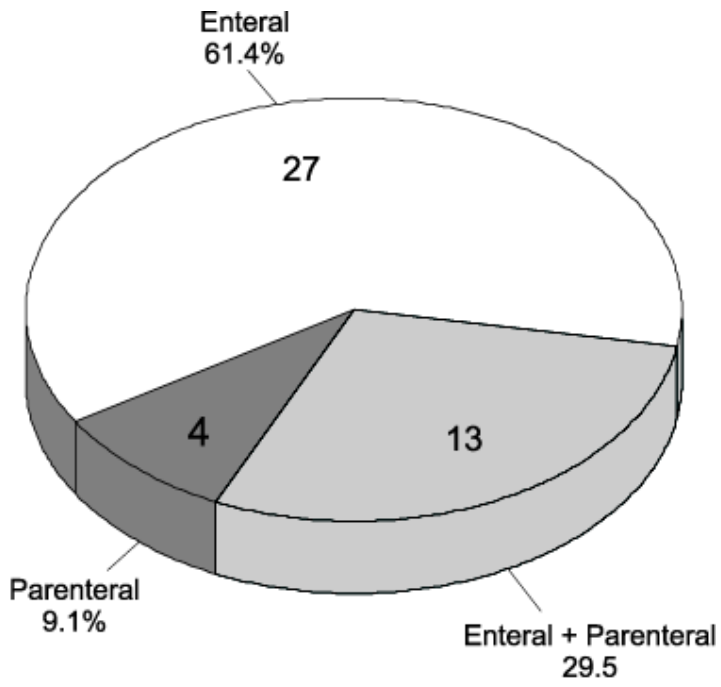

Figure 1 - Nutrient administration route in patients with acute neurological diseases.

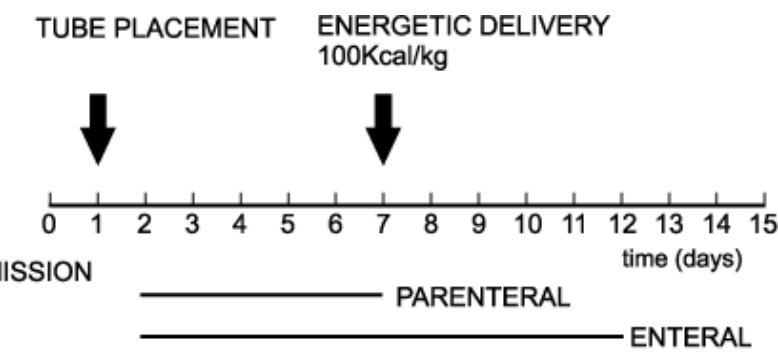

Figure 2 - Chronogram of nutritional support (values expressed as median).

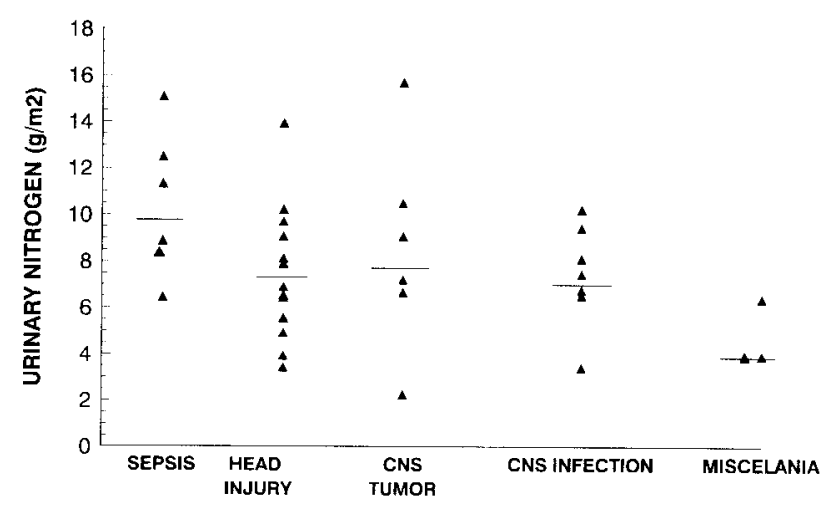

Figure 3 - Values of urinary urea nitrogen at admission, according to the diagnosis (median and individual values).

\section{DISCUSSION}

Patients with acute CNS disease present problems that, although not being specific, make nutritional metabolic therapy more difficult. CNS injury initiates a metabolic response similar to that which occurs with

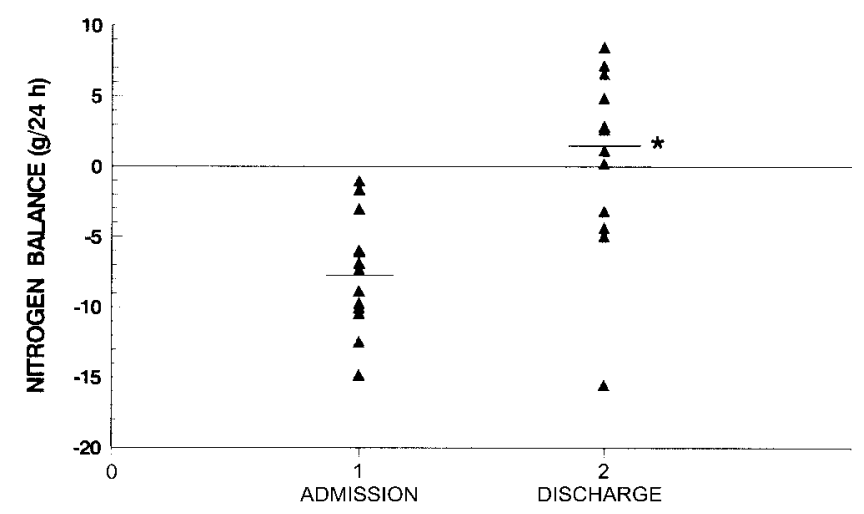

Figure 4 - Nitrogen balance at admission and at discharge from the PICU, for patients with acute neurological diseases (median and individual values).

* discharge $>$ admission $(p<0.01)$

patients with sepsis or trauma. ${ }^{13,14}$ This response is characterized by hypermetabolism, hypercatabolism, altered vascular permeability, and altered GI function.

Hypercatabolism may lead to acute malnutrition which, depending on the degree and period of stress and on the previous conditions of the patient, can result in a significant loss of body mass. This metabolic response may vary according to the specific clinical situation. ${ }^{15,16}$ In the present study, the patients presented initial urinary urea nitrogen values of variable although generally high amplitude, which resulted in negative nitrogen balances at admission. This was observed in children with traumatic, infectious or inflammatory lesions.

There is great variability of metabolic response according to the clinical situation. Patients with similar Glasgow scores may present different nitrogen losses. Even in the case of identical CNS lesions, the complications and therapeutical approaches may interfere with the magnitude of the metabolic response. Sepsis, therapy using steroids, ${ }^{17}$ sedatives ${ }^{18}$ and neuromuscular blocking agents ${ }^{19}$ may also affect nitrogen losses and energy expenditure. As in other situations, there are individual variations in energy and oxygen consumption. Patients with decerebration and decortication have greater energy needs, whilst the needs are smaller in patients in barbituric coma ${ }^{20}$ or who are tetraplegic. ${ }^{21,22}$

Studies in adult patients with head trauma have shown increases of over $50 \%$ in basal energy expenditure. ${ }^{23}$ Weekes and $\mathrm{Elia}^{24}$ observed energy expenditure increased by $30-35 \%$ above the estimate and that this increase was directly related to temperature and interruption in sedation. It has been suggested that energy needs do not necessarily increase, since the decrease in physical activity that accompanies the disease is sufficient to counterbalance this effect and, thus, the increase does not really occur. 
In the present study, the increased loss of urinary urea nirogen observed in children with Guillain-Barré syndrome suggests the existence of a hypercatabolic state, probably triggered by endocrine and inflammatory components of the disease. An increase in urinary urea nitrogen excretion was also observed by Roubennof et al in adults with Guillain-Barré syndrome. ${ }^{25}$ In their study, the authors drew attention to the false impression that patients suffering from this disease were maintaining good nutritional status, a fact that often delays the implementation of adequate nutritional support.

The nitrogen balance may be a useful tool for tailoring protein supply to the individual needs of each patient, as has been shown in our study. In fact, the increase in nitrogen balance was made possible by the significant increase in protein delivery, since no variation in nitrogen loss was detected between the start and end points of the assessment. The increase in protein delivery is aimed at minimizing nitrogen losses and at partially compensating the hypercatabolism. Even though the supply of aminoacids may increase protein synthesis, it is not sufficient to reach protein anabolism in the short run. ${ }^{26} \mathrm{In}$ children with head trauma or with severe CNS infection, a nitrogen to non-protein calorie ratio of $1: 150$ to $1: 100$ is recommended..$^{27}$

Patients with acute CNS disease are frequently comatose or have impairment of swallowing reflexes, generally receiving parenteral or enteral tube feeding. Enteral nutrition presents several obvious advantages over parenteral nutrition, since it is more physiological, its costs are lower and it presents a lower incidence of complications. Patients with acute neurological disease present clinical conditions than clearly, more than in any other disease, justify the indication of enteral tube feeding: 1) the presence or risk of malnutrition, in which the oral route is insufficient to avoid weight loss; and 2) neuromuscular impairment with a high probability of bronchoaspiration of gastric contents.

Clinical studies have demonstrated improvement in immunocompetence and survival in neurosurgical patients who were given early nutritional support, and that nutrient delivery by the enteral route is safe when there is viability of the digestive tract. Sachs et al observed improvement in immunological function, assessed by the CD-4/CD-8 relationship and tests stimulating $\mathrm{T}$-lymphocyte proliferation in patients with brain injury who had received early enteral nutrition. ${ }^{28}$

Enteral tube feeding must be an obligatory component of the therapeutic plan for patients with acute neurological diseases and it may be administered by an intragastric or post-pyloric route. The intragastric route requires that the swallowing and coughing reflexes be preserved, that the esophagic sphincter be functional and that gastric motility be maintained. The post-pyloric route must be employed in those patients who present impaired protection of the respiratory tract or delayed gastric emptying, situations which give rise to greater probability of bronchoaspiration. ${ }^{29}$ Patients under metabolic stress frequently present some degree of gastric atony. Factors such as sepsis, increase in intracranial pressure and the use of drugs such as opiates and dopamine, amongst others, affect the hormonal control of GI tract motility, abolishing the activity of migratory motor complexes in the gastric antrum..$^{30}$ Saxe et al, ${ }^{31}$ studying head-injured patients, observed dysfunction of the lower esophageal sphincter, suggesting that intra-gastric enteral nutrition would not be a safe method for nutrient delivery. It has also been suggested that regurgitation is a common event in headinjured patients who receive intra-gastric tube feeding and that the use of the post-pyloric route presents advantages over the intra-gastric route in these patients. ${ }^{32}$ Thus, in situations where there is a high probability of delayed gastric emptying, feeding tubes placed beyond the pylorus allow for the provision of higher volumes of the diet at an earlier time, with a lower risk of aspiration or bronchopneumonia, when compared to the intragastric route.

In the present study, enteral tube feeding was initiated two days after patient admission, constituting early beginning as defined in the literature. ${ }^{33}$ The authors took into account that the median period of seven days needed to reach the planned energy delivery may be deemed short, considering the high proportion of patients with head injury or in the craniotomy post-operative period following brain tumor exeresis, situations in which sedatives for decreasing digestive tract motility are frequently used. A study with adult head-injured patients showed a median time of 11.5 days for achieving the planned energy delivery. ${ }^{34}$ There are no references regarding this particular aspect in pediatric studies.

Polymeric enteral diets are generally well tolerated, although the use of pre-digested ones, based on hydrolyzed protein, may be indicated in an initial phase of the treatment. This type of diet is preferred when there is persistent diarrhea or sepsis, situations in which there is reduction in absorptive surface and increase in permeability of the intestinal mucosa. ${ }^{35}$ The frequency of diarrhea varies from 5 to $32 \%{ }^{36}$ and it presents multifactorial etiology. Osmolality and diet infusion mode, bacterial contamination, hypoalbuminemia, use of antiacids and antibiotics and intestinal mucosa lesions are the most frequently reported factors. ${ }^{37}$

The low frequency of GI tract complications in this study could be attributed to the early implementation of 
feeding by the digestive route, which may improve tolerance to the nutrients and, by strengthening the trophism of the intestinal epithelium, may act as a prophylactic against mucosa lesions. It is significant that none of the patients fed by the enteral route developed peptic ulcer, a complication that occurred in two of the four patients on exclusively parenteral nutrition. The association of stress and starvation promotes alterations in the function and trophism of the intestinal mucosa, characterized by decrease in secretory IgA and bacterial adherence of inflammatory macromolecules. ${ }^{38}$ Nutrition by the digestive route thus acquires great importance as a protective measure for preventing alterations to the integrity of the intestinal mucosa, and to the barrier function it performs during stress.

Metabolic complications like hypernatremia can occur in infants who have received diets formulated for adult patients which, due to their greater concentration of electrolytes, are not appropriate for use in pediatric patients. Severely undernourished patients may undergo hypophosphatemia and hypopotassemia when they reach nutritional recovery, needing supplementation of these ions.

Based on evidence presented in the literature and on acquired experience, the authors suggest that early nutritional regimens using small bowel feeding should be attempted whenever possible. If there is hemodynamic stability and if the digestive tract is functioning, enteral nutrition can be beneficial with the use of adequate diets, administered by continuous infusion. When fluid restriction is indicated, formulae with higher energy content may be used. Since nutrient delivery by the enteral route does not initially fulfill the needs of acutely ill patients, the concomitant administration of parenteral nutrition is generally needed in this phase, while the enteral nutrition promotes the stimulation of the GI tract. The nursing staff should be educated regarding the risk of aspiration and poor gastric emptying in enteral tube-fed patients.

Monitoring of metabolic stress and response to the administration of nutrients must be performed at regular intervals, providing means of verifying the efficacy of the therapy and the degree of intolerance to nutrient delivery, adjusting it according to the patient's needs. The use of formulae based on the determination of urea nitrogen in the 24 hour urine is useful for estimating the total nitrogen loss. Urea nitrogen has a good correlation with total nitrogen $^{39,40}$ and it has been used in evaluating the degree of metabolic stress and planning the protein offer. The amount of nitrogen excreted in the urine reflects the magnitude of the breakdown of muscular protein and the degree of hypercatabolism.

The nitrogen balance, obtained from the difference between the losses and the administration of nitrogen, in spite of the difficulties inherent in serial collection of 24 hour urine, is still the simplest and quickest method for the assessment of protein metabolism in the short run, as well as for evaluating the efficacy of nutritional support in hypercatabolic patients. Glycemic levels must be routinely monitored, due to the risk of neurological lesions and possible association with worsened prognosis in head injuries. ${ }^{41,42}$ The serum levels of triglycerides in critically ill children receiving intravenous lipid emulsions must also be monitored, since in this situation there may be a reduction in lipid clearance, with deposition in the vascular endothelium and reticulo-endothelial system. The serum levels of triglycerides must be determined before the start of infusion and whenever there is an increase in lipid delivery, maintaining levels below $200 \mathrm{mg} / \mathrm{dl}$.

The results of this study have demonstrated that patients with acute neurological diseases are hypercatabolic and that the negative nitrogen balance can be reversed by more aggressive nutritional support than that commonly used. Early enteral nutrition was well tolerated, demonstrating that it is a safe and effective method for the administration of nutrients. It should be emphasized, however, that the success of enteral nutrition is directly related to the motivation and performance of the medical, nursing and nutritional team. Awareness of the advantages of early use of enteral tube feeding, its administration using correct techniques and appropriate diets, accompanied by continuous monitoring and care by nursing personnel, are essential factors in improving the quality of nutritional support in children with acute neurological diseases.

\section{REFERENCES}

1. Drew JH, Koop CE, Grigger RP. A nutritional study of neurosurgical patients. J Neurosurg 1947;4:7-15.

2. Cerra FB. Hypermetabolism, organ failure and metabolic support. Surgery 1987;101(1):1-13.

3. Young AB, Ott L, et al. The effect of nutritional support on outcome from severe head injury. J Neurosurg 1987;67:668-76.

4. Endersbe LA. Nutrition Support in Neurologic Impairment. In: Shronts, Eva P, editors. Nutrition support dietetics. Maryland, Aspen: Silver Spring 1989;107-18.

5. Jacksic T, Blakburn GL. Nutrition and CNS disease, the unconscious patient. In: Jeejeebhoy $\mathrm{KN}$, editor. Current 
therapy in nutrition. Toronto, Philadelphia: B C Decker Inc. 1988;269-78.

6. World Health Organization. Medición del Cambio del Estado Nutricional. Geneva; WHO 1983;105.

7. Waterlow JC. Classification and definition of protein-calorie malnutrition. Br Med J 1972;3:566-9.

8. Batista-Filho M, Sigulen DM, Nóbrega FJ. Nomenclatura e classificação da desnutrição. $1^{a}$ parte. J Ped 1976;41:45-51.

9. Wilmore DW. The metabolic management of the critically ill. New York: Plenun Publishing Corporation 1980;262.

10. ASPEN Board of Directors: guidelines for the use of parenteral and enteral nutrition in adult and pediatric patients. JPEN 1993;17(4):1SA-52SA.

11. Holliday MA, Segar WE. The maintenance need for water in parenteral fluid therapy. Pediatrics 1957;19:823-32.

12. Siegel S. Estadistica no parametrica. Mexico: Trillas 1975;346.

13. Ott L, Young B, et al. The metabolic response to brain injury. J Parent Ent Nutr 1987;11(5):488-93.

14. Young AB, Ott LG, et al. The acute-phase response of the brain-injured patient. J Neurosurg 1988;69:375-80.

15. Phillips R, Ott LG, et al. Nutritional support and measured energy expenditure of the child and adolescent with head injury. J Neurosurg 1987;67:846-51.

16. Roberson C, Cormio M. Cerebral metabolic management. New Horizons 1995;3:410-22.

17. Haynes RC, Murad F. Hormona adrenocorticotrofica, esteroides adrenocorticales y sus análogos, sintéticos inibidores de la biosíntesis de esteroides corticosuprarenales. In: Goodman y Gilman, editores. Las bases farmacológicas de la terapéutica. Buenos Aires: Panamericana 1982;1430-58.

18. Bruder N, Dumon JC, François G. Evolution of energy expenditure and nitrogen excretion in severe head-injured patients. Crit Care Med 1991;9:43-8.

19. Clifton GL, Robertson CS, Choi SC. Assessment of nutritional requirements of head-injured patients. J Neurosurg 1986;64:895-901.

20. Dempsey DT, Guenter P, Millen JL, et al. Energy expenditure in acute trauma to the head with and without barbiturate therapy. Surg Gynecol Obstet 1985;160:128-34.

21. Kolpek JH, Ott LG, et al. Comparison of urinary urea nitrogen excretion and measured energy expenditure in spinal cord injury and nonsteroid-treated severe head trauma patients. JPEN 1989;13(3):277-80.

22. Dietrick JE, Whedon GD, Shorr E. Effects of immobilization upon various metabolic and physiologic functions of normal men. Am J Med 1948;4:3-36.

23. Roberts PR. Nutrition in the head-injured patient. New Horizons 1995;3:506-17.

24. Weekes E, Elia M. Observations on the patterns of 24-hour energy expenditure changes in body composition and gastric emptyng in head-injured patients receiving nasogastric tube feeding. JPEN 1996;20:31-7.
25. Roubenoff RA, Borel CO, Hanley DF. Hypermetabolism and hypercatabolism in Guillain-Barré syndrome. JPEN 1992;16(5):464-72.

26. Leite HP, Carvalho WB, Fisberg M. Nutritional and metabolic assessment of critically ill childen. Rev Paul Med 1996;114:1173-6.

27. Twyman D, Young AB, et al. High protein enteral feedings: a means of achieving positive nitrogen balance in head injured patients. JPEN 1985;9(6):679-84.

28. Sacks GS, Brown RO, Teague D, et al. Early nutrition support modifies immune function in patients sustaining severe head injury. JPEN 1995;19(5):387-91.

29. Olivares L, Segovia A, Reavuelta R. Tube feeding and letal aspiration in neurological patients: a review of 720 autopsy cases. Stroke 1974;5:654-7.

30. Dive A, Moulart M, Jonard P, et al. Gastroduodenal motility in mechanically ventilated critically ill patients: a manometric study. Crit Care Med 1994;22(3):441-7.

31. Saxe M, Ledgerwood AM, Lucas CE, Lucas WF. Lower esophageal sphincter dysfunction precludes safe gastric feeding after head injury. J Trauma 1994;37:581-6.

32. Grahm TW, Zadrozny DB, Harrington T. The benefits of early jejunal hyperalimentation in the head-injured patient. Neurosurgery 1989;25:729-35.

33. Minard G, Kudsk KA. Is early feeding beneficial? How early is early? New Horizons 1994;2:156-63.

34. Norton JA, Ott LG, McClai C, et al. Intolerance to enteral feeding in the brain injured patient. J Neurosurg 1988;68:62-6.

35. Johnston JD, Harvey CJ, Mengies IS, et al. Gastrointestinal permeability and absorptive capacity in sepsis. Crit Care Med 1996;24:1144-9.

36. Gottschlich MM, Warden GD, et al. Diarrhea in tube fed patients: incidence, etiology, nutritional impact, and prevention. JPEN 1988;12:338-45.

37. Silk D, Payne-James J. Complications of enteral nutrition. In: Rombeau JL, Caldwell MD, editors. Enteral and tube feeding. Philadelphia: W B Saunders Company 1990;614.

38. Spitz JC, Ghandi S, Taveras M, et al. Characteristics of the intestinal epithelial barrier during dietary manipulation and glucocorticoid stress. Crit Care Med 1996;24:635-41.

39. Velasco N, Long CL, Otto DA. Comparison of three methods for the estimation of total nitrogen losses in hospitalized patients. JPEN 1990;14(5):517-22.

40. Milner EA, Cioffi WG, Mason-Jr AD, Mcmanus F, Pruitt-Jr BA. Accuracy of urinary urea nitrogen for predicting total urinary nitrogen in thermally injured patients. JPEN 1993;17:141-416.

41. Young B, Ott L, Dempsey R, et al. Hyperglycemia and neurological outcome of severely brain-injured patients. Ann Surg 1989;210:466-73.

42. Michaud LJ, Rivara FP, Longstreeth WT. Elevated blood glucose levels and poor outcome following severe brain injuries in children. J Trauma 1991;31:1356-62. 


\section{RESUMO}

Objetivos: Relatar a experiência com a terapia nutricional e metabólica em crianças com neuropatias agudas - com ênfase na avaliação metabólica e no uso da nutrição enteral - e propor medidas mínimas para a sua implementação. Pacientes e Métodos: Análise retrospectiva do padrão de terapia nutricional e metabólica de todos os pacientes com neuropatia agudas consecutivamente admitidos na UTI durante um período de três anos. Traumatismo craniano, infecção do SNC e pós-operatório de retirada de tumor cerebral foram os principais diagnósticos. Resultados: Dos 44 pacientes estudados, $61,4 \%$ receberam nutrição enteral exclusiva, 9,1\% nutrição parenteral exclusiva e $29,5 \%$ por ambas as vias. A via enteral foi utilizada em $79,1 \%$ e a via parenteral em $34,3 \%$ do tempo total de 527 dias de terapia. A sonda enteral era introduzida na admissão, ocorrendo migração para o duodeno em $90 \%$ dos casos. A nutrição enteral pós-pilórica iniciou-se dois dias após a internação. As necessidades energéticas estimadas foram satisfeitas no sétimo dia de admissão quando era então suspensa a nutrição parenteral. A oferta energética máxima foi $104,2 \pm 23,15 \mathrm{kcal} / \mathrm{kg}$. O tempo mediano de terapia foi de 11 dias (variação de quatro a 38 dias). Nenhuma criança em nutrição enteral desenvolveu hemorragia digestiva, pneumonia ou episódio de broncoaspiração e, dos quatro pacientes que receberam nutrição parenteral exclusiva, dois desenvolveram úlcera péptica. A excreção urinária de nitrogênio uréico foi elevada, sendo $7,11 \mathrm{~g} / \mathrm{m}^{2}$ na admissão e $6,44 \mathrm{~g} / \mathrm{m}^{2}$ na alta. A oferta protéica passou de $1,49 \mathrm{~g} / \mathrm{kg} / \mathrm{dia}$ para $3,65 \mathrm{~g} / \mathrm{kg} / \mathrm{dia}(\mathrm{p}<0,01)$ e o balanço nitrogenado de $-7,05 \mathrm{~g}$ na admissão para $2,2 \mathrm{~g}$ quando da alta da unidade $(p<0,01)$. Conclusões: As neuropatias agudas levam a um estado ao hipercatabólico, com elevadas perdas nitrogenadas. $O$ balanço nitrogenado negativo pode ser revertido por regimes mais agressivos do que os habitualmente utilizados. A nutrição enteral iniciada precocemente foi bem tolerada, demonstrando ser um método seguro e efetivo para a administração de nutrientes. 